\title{
SLOVENIAN IMMIGRANTS AND THE ETHNIC ECONOMY IN CONTEMPORARY CANADA
}

\author{
Mitja DURNIK
}

COBISS 1.01

\begin{abstract}
Slovenian Immigrants and the Ethnic Economy in Contemporary Canada

The Slovenian community in Canada, although a small constitutive element of the current population, has actively contributed to the economic and political development of the second-largest country in the world. Previous studies have only descriptively addressed the role of Slovenian immigrants in the construction of this important economic system. This paper argues that the development within the community has brought about some significant changes in social stratification among its members, specifically with regard to the radical global economic challenges of recent decades. On the other hand, the specific altruistic mission of Slovenian community organisations has remained largely unchanged.

KEY WORDS: migration, Slovenian immigrants, ethnic economy, Canada
\end{abstract}

\section{IZVLEČEK}

Slovenski priseljenci in etnična ekonomija sodobne Kanade

Čeprav je slovenska skupnost v Kanadi le majhen konstitutivni element sodobne države, je aktivno prispevala k ekonomskemu in političnemu razvoju druge največje države na svetu. Dosedanje študije so le deskriptivno raziskovale vlogo slovenskih izseljencev v gradnji tega pomembnega gospodarskega sistema, v pričujočem članku pa avtor analizira razvoj slovenske skupnosti in pomembne spremembe v družbeni stratifikaciji članstva glede na radikalne globalne gospodarske spremembe. V nasprotju s tem pa so organizacije slovenske skupnosti v Kanadi ohranile altruistično poslanstvo, ki je v različnih obdobjih ostalo domala nespremenjeno.

KLJUČNE BESEDE: migracije, slovenski priseljenci, etnična ekonomija, Kanada

PhD in Political Science, Assistant Professor, Faculty of Administration, University of Ljubljana, Gosarjeva ulica 5, SI-1000 Ljubljana; mitja.durnik@fu.uni-lj.si 


\section{PROLOGUE}

Immigration had a significant impact on Canadian post-war development, especially since it acted as a factor of transformation of the entire society and changed the structure of classes (Stasiulis 1997). The development of the nation-state was intensively planned as a mixture of economic policy and immigration (Simmons 2010). The period after the Second World War was a period of recovery for the Canadian economy, which stimulated a need for new workers, especially in resource-based industries such as mining and farming. During the last three decades or so, modern Slovenian immigrants ${ }^{1}$ have come to Canada as a well-educated workforce, and have begun to establish intensive economic ties with their home country.

In Canada, there has been an ongoing debate on whether immigration has had solely positive impacts on economic development. Broadly speaking, numerous authors have pointed out the importance of increased overall GDP as a consequence of immigration. Less attention has been given to the "link between increasing the total size of the economy and individual well-being" (Riddell, Worswick, Green 2016). One of the mainstream theses in this sense is that to a very limited extent it influences employment levels and wage rates (ibid.). On the other hand, following the Liberals' agenda, increasing immigration into the country is one of the major political goals of Trudeau's government in the coming years (A New Plan 2016). Of course, there are different opinions about the possible impacts on the national economy. Gignac (2013), for example, showed that immigrant workers are largely well-integrated into the workforce and quickly adopt the needed skills. Dungan, Fang and Gunderson (2012) additionally note the welcome impacts on real GDP and GDP per capita, aggregate demand, investment, productivity, government expenditures, taxes etc.

The Slovenian community in Canada has contributed only a small amount to the overall national economy. Despite its smallness, we are aware how the structural dynamics of the Slovenian ethnic economy have changed throughout Canada's history of economic development. We can conclude that some important social institutions have remained mostly intact due to their supporting role within the system of the ethnic economy - banks, associations, clubs etc. To date, small (ethnic) economies have followed the rule of sustainability and economic balance much more closely than dominant capitalist production. With regard to the contemporary economic development of the Slovenian diaspora in Canada, there are two crucial aspects. Firstly, what is the impact of the latest immigration wave of Slovenians after the global economic crisis on the development of the Slovenian community in Canada? Secondly, what is the relevancy of the ethnic community in mediating trade relations between Slovenia and Canada? As we will show below, these two parameters are undoubtedly interlinked. Newcomers to Canada bring contemporary knowledge about Slovenian society and the Slovenian economy, and about what is needed to improve their prosperity. On the other hand, pure entrepreneurial interest is often mixed with strong nostalgia, particularly among the older generations in Canada.

1 The term "immigrants" is used from the Canadian perspective to denote Slovenians who migrated to Canada. 


\section{METHODOLOGICAL APPROACHES}

From a theoretical point of view, in the present study we have used the rich tradition of Canadian political and economic thought, which set immigration, ethnicity and race as one of its focal points of investigation. Additionally, the ideas of some prominent international thinkers in the field of ethnic economy and migration studies support the specific Canadian approach to the historical economic development of immigrants. A virtual presentation (Durnik 2012) made by the author, which was part of an exhibition called Images of Canadian Slovenians (Strle 2012), and which also served as the basis for the present paper, included a historical overview of Slovenian immigration. This was the first exhibition about Slovenians in Canada to use theoretical approaches and data from Canadian economic history combined with a historical approach based on immigrants' life stories and experiences (the Slovenian perspective).

With regard to economic development in the last decade or so, the database of the Canadian Slovenian Chamber of Commerce (hereinafter CanSlo) has been an excellent resource for determining the structural underpinnings of the ethnic economy in the modern era. Currently, there is no other relevant source of information concerning contemporary Slovenian entrepreneurship in Canada. This paper is unique in the sense that it traces a completely new research field relevant for the Slovenian community in Canada. However, we assume that the lack of relevant data significantly limits the development potential of ethnic entrepreneurship. Lastly, the author's fieldwork notes (Notes on Fieldwork 2016) are an important source for detecting the business patterns of the most recent generation of Slovenians in Canada, especially those who migrated to the country in the years following the beginning of the global financial crisis. The notes were written in regard to contacts with the Slovenian community at various events - business meetings, social club events, etc.

\section{THEORETICAL ASSUMPTIONS}

The role of the state in development issues has been crucial for the development of the modern Canadian staple economy. Immigrants have also played an important and integral part, as a reservoir for the required workforce. Specifically, when immigration to Canada adopted a transnational character, the state decided to attract specifically higher-educated immigrants to fill empty posts in the banking sector, IT companies, etc. The latter trend is significantly different to all of the other post-WWII immigrant waves when Canada particularly needed miners, farmers, craftsmen and other workers who helped shore up Canada's industries and transport infrastructure, and who also responded to the growing need for housing and the developing service sector.

Simmons (2010) has pointed out that Liberalists have often linked immigration with neoclassical economics, stressing that movement of people from one place to another is usually voluntary. Here we have two possible explanations of the neoclassical view. Firstly, the macroeconomic standpoint that explains the role of the market in migration waves, where the difference in wages between the country of origin and the host country could 
be a potential factor for migration. ${ }^{2}$ The microeconomic aspect is strongly affected by the rational choice theory - an individual analyses the costs and benefits of moving out of the country ${ }^{3}$ (Mesić 2002). Frisbie (1975) showed how increased productivity and higher wages among Mexican farmers resulted in reduced emigration from Mexico to the US. In contrast to neoclassicism, the Marxist view, representing the dispersed heterodox school, negates the positive implications of migration. Marxist scholars insisted that the capitalist mode of production uses immigrants as a "reserve army of labour".

The "New Economy" model has partially opposed some of the fundamental standpoints of its counterpart. Namely, neoclassical scholars agree that individuals migrate permanently to another country in order to maximize their wages. On the other hand, the new economy approach treats return migration as success (Porumbescu 2015). Families in poorer countries often send some of their members to developed economies on a temporary basis, and may depend on them for their survival. The so-called "push-pull" model referred to the question of different business opportunities (e.g. wages, working conditions) between the country of origin and the desired destination. The approach was originally developed in order to describe internal migration within countries, and as such had a limited ability to explain migration flows. The paradigm has been further explained as a twoway systemic causation in the sense of surviving households. In addition to the movement of migrants between the two countries, the flow of information between communities has also been identified as crucial (Simmons 2010).

The World System Theory has been largely critical of the exploitation of the capitalist mode of production in peripheral areas. At the same time, capitalism has provoked migrations from those territories and people have decided to migrate directly to the largest global metropolises. Subsequently, the theory of global cities advocated that urban centres have become the nexus of financial, technological and investment flows. The role of information technology and the fact that industry is no more a vehicle of world development are especially significant - we are witnesses to the process of deindustrialization and the growth of the service sector. Similarly, within the network approach scholars have investigated the potential of migrants' networks as interpersonal connections. The members of these networks may be immigrants of different generations, their relatives and other individuals from different ethnic groups. These networks operate as diffusive structures outside the remit of governmental supervision (Mesić 2002).

2 Of course, using solely macroeconomic explanations is too narrow to describe the immigration periods between and after the two world wars. The post-war period had an enormous impact on global economic relations, whereas a large part of Europe was destroyed. WWII was followed by a prolonged degree of violence and a long period of general stabilization (see Judt 2007; Lowe 2012). It seems crucial to point out that migration patterns have been radically different in periods of peace than in times of war. In fact, in this sense the economic aspects have been mixed up with harsh political realities. Specifically, the first years after WWII in the former Yugoslavia were largely characterized by the complex political situation, and for this reason the country's development opportunities were limited. Even in the contemporary migration context, it is almost impossible to exclude economics from politics.

3 One important parameter is the ratio of inequality between classes in a society. At the beginning of every international conflict, radical inequalities have provoked international wars. Unsurprisingly, the human race has usually learned something important after shocking historical events (see Picketty 2014; Milanović 2016). 


\section{Ethnic economies and community altruism}

Without any state intervention, immigrant communities have often developed separate institutions that arrange for the basic survival of their members at the very beginning and later throughout the development process. We can speak about "micro-level" politico-economic processes at the community level. Vah Jevšnik and Lukšič Hacin (2011) showed theoretical differences in defining the contexts of ethnic economies in Europe and North America - how the (neo)liberal and social models as macroeconomic and political platforms affect the bias of ethnic economies. In this sense, the authors (2011) specifically emphasize the different roles of the state in both traditions. In the United States, immigrant/ ethnic business initiatives, for example, fall under the rules of the market. On the contrary, in Europe, these business initiatives are often supported by the state, underlining the importance of better integration into mainstream society.

Light and Gold (2000: 4), prominent thinkers in the field of the ethnic economy, have explained that it "consists of co-ethnic self-employed and employers and their employees". The influence of the structure of an ethnic economy depends on the size of the system. The ethnic economy is divided into three distinct subgroups. Firstly, in the "ethnic ownership economy" the ethnic group or immigrant community "maintains a private economic sector in which it has a controlling ownership stake" (Light, Gold 2000: 9). Family members may act as supporters to established businesses, often as unpaid assistants. Secondly, the "ethnic enclave economy" is referred to in correlation with the dual labour market theory. In contrast to neoclassical economics, scholars recognized an anomaly in the sense that the members of some marginal communities are "locked" inside a subordinated labour market and cannot enter the "primary sector" where better jobs are available. Immigrants are part of an "enclave" job market if their employers are co-ethnic. Ethnic enclave economies are territorially delimited and quasi-monopolistic. Vertical and horizontal linkages between firms and co-ethnic spending give the structure a certain advantage with respect to the external business environment. Thirdly, the term "ethnic-controlled economy" describes the situation where co-ethnic employees exercise extensive influence and power in the dominant economic system.

In fact, there are at least two radically different visions explaining the nature of the ethnic economic structure. The assimilation paradigm refers to the incremental loosening of socio-economic contacts with the country of origin. On the other hand, transnationalism has been the predominant model in the last few years for explaining new types of cooperation and information flows between the new dominion and the country of origin (Fong, Cao, Chan 2010: 445). Usually, larger ethnic groups in Canada have had far greater potential for establishing transnational ties with the country of origin. It has been shown, for example, that Chinese people and Asian Indians have not fully exploited the potential of transnational networking in terms of the internationalisation of ethnic business. Research findings have shown that only a small percentage of immigrants fully realise intensive transnational contacts (Fong, Cao, Chan 2010). The distinction between the terms "immigrant" and "ethnic" entrepreneur, clearly elucidated by Žigon (2012), seems to be fundamental. Immigrants decide to move to a new homeland and establish their basic survival subsystem there. Their ethnic counterparts are, for example, Canadian Aboriginals, who developed their distinct mode of production a long time ago. Furthermore, the 
aboriginal economic system has been in a constant clash with the different development phases of capitalism, but also in close contact with this dominant mode of production.

Every ethnic community has been partially historically organised as a "living" structure which has supported its members (flawed system of social, health or accident insurance, covering of funeral costs in cases of accidents involving Slovenian miners etc.). Some of the historically important support organisations have been developed as non-profit organisations in Canada and the United States. Modern insurance cooperatives or social clubs are examples of historical solidarity between the members of the Slovenian community (Žigon 2012). We have to differentiate between "old" and "new" institutions within the development of any immigrant community. As in other communities, in the Slovenian case immigrants brought various conventional patterns as such those from the church or family, and integrated them into the new environment. On the other hand, they have established some completely new ones, for example business organisations. However, the most important social institutions are still the social clubs, ethnic associations and religious organisations. All of the above-mentioned ethnically-based organisations have accomplished tasks as solidarity facilitators, cultural-educational missions, religious and economic support groups, etc. (Pospeh 2009).

\section{The history of Slovenian immigration in Canada}

Slovenian immigration in Canada is a mixture of political and economic aspects, with the latter predominating over time (Strle 2007). Until WWII, immigrants moved to Canada mostly due to severe economic conditions in their homeland. Canada accepted its first immigrants from modern-day Slovenia very late compared to the United States, around a decade after WWI. According to some data, they worked in mining and farming; some of them were so-called "gold-seekers". After 1924, when the USA closed borders to mass immigration, Canada became the promised land ${ }^{4}$ for escaping economic underdevelopment in the homeland (Genorio 1979). Genorio also observed another phenomenon relating to the latter period: many Slovenians who initially immigrated to Canada later moved to the USA. The towns of Kirkland Lake and Timmins in northern Ontario were the largest concentrated areas populated with Slovenians due to the mining industry, and in some minor parts also due to the automobile industry and the light machine industry (Strle 2009; Genorio 1979).

Following Strle (2007), the period after WWII represented the first real boom of immigration from then-communist Yugoslavia. In contrast to the pre-war period, immigrants mostly settled in urban areas instead of rural. These Slovenians possessed better educational and working qualifications than the previous wave of immigrants, despite the fact that some time was needed for certification of documents on a regular basis. Slovenian post-war immigration was also sharply divided on a political basis. Another often-neglected phenomenon was transmigration, when some individuals and families migrated back to the homeland due to negative experiences in Canada. Some of them then decided to return to Canada, disappointed with the new regime and politico-economic conditions in Yugoslavia

4 Speaking in the North-American context. For example, South American countries such as Argentina, on the contrary, encouraged immigration. 
(Strle 2007). Genorio (1979) states that 1,869 individuals returned to their homeland in 1947 and 1948. In relation to other Yugoslav nationalities, Slovenians accounted for a small proportion of the overall transmigration wave.

In the 1970s and 1980s, the so-called brain-drain to a significant extent replaced the political motivations of the previous era. At the same time, the new immigrants were faced with a very new idea, nowadays known as multiculturalism. Above all, the new Canadian visa regime liberalised immigration policy towards Yugoslavia (Strle 2007). Genorio (1979) compared data for 1971 and 1976, and concluded that Slovenians represented only 6-8 percent of overall Yugoslav immigration. On the other hand, many Slovenian immigrants declared themselves as Yugoslavs during this period. $80 \%$ of Slovenians inhabited the province of Ontario. Pospeh (2014) has noted that many family members of post-war political refugees, pre-war economic immigrants and illegal fugitives immigrated into Canada during the third wave (somewhere between 1957-1970/1971). Data on Slovenians living in Canada vary from one author to another. According to Pospeh (2014), the Slovenian community in Canada includes somewhere between 35,000 and 40,000 members, $25 \%$ of whom live in Toronto. Comparing different periods in Canadian history, the larger metropolitan areas have become more attractive for settlement due to their many economic and social advantages.

In the last decade or so (from 2007 onwards), the global financial and economic crisis has radically provoked international migration to North America and other parts of the world. Under these circumstances, some Slovenians also immigrated to Canada due to better employment opportunities. What may be surprising is that the Canadian labour market has not been solely opened up to highly-educated workers; employers are aware that they can find well-qualified individuals in construction and various other conventional industries (Notes on Fieldwork 2016).

\section{Organizations of Canadian Slovenians}

When newcomers enter a new potential homeland, they often set up their own institutions and collaborative networks. Usually, they are the primary creators of these interactions, but other ethnic groups and individuals may participate. An institutional arrangement is often unavoidable due to the fear of possible isolation (Genorio 1989). Using the language of ethnic economy, immigrants try to establish a sustainable internal microeconomic system, which is more or less integrated within the dominant capitalist production. The integration level is possibly dependent on the size of the community and the power of its network structure. In our view, we understand the social and economic institutions of the Slovenian community as actively interdependent structures. The social institutions have always supported any entrepreneurial activities within the community. Some sociologists have defended the thesis that less-assimilated ethnic communities usually build up stronger institutional systems (Genorio 1989).

Genorio (1989) divided Slovenian immigrant institutions into the following categories: social/solidarity institutions, cultural organisations, political organisations, religious structures, economic associations and immigrant family circles. Some of the first organized interests were joined into so-called "support units", which often operated as insurance companies covering basic social security services for their members. Sometimes the existence 
of these "brotherhoods" was fragile due to the many internal migrations within Canada. Significant political immigration into Canada occurred after WWII, and consequently religious organisations became visible for the first time as an important institutional player within the community. When the younger population immigrated to Canada, some new cultural societies started operating. Slovenian associations in Canada are coordinated by three main umbrella organisations (Pospeh 2014):

- The All Slovenian Committee is a non-profit organisation managing activities of the majority of Slovenian associations in Southern Ontario (Niagara Peninsula). Established at the beginning of the 1990s, it has tried to overcome important disagreements among organisations at different ranks.

- The Slovenian Canadian Council was established in Toronto in 1978 and largely represents Slovenian political emigrants. One of its main duties is the process of acquisition of Slovenian citizenship, questions of denationalization of pre-war private property, voting rights of Slovenians in Canada etc. Its main disadvantage was that it could not unite the majority of immigrants in Canada due to its strict stance regarding economic emigration.

- The Canadian Slovenian Congress was established in Toronto in 1990 and was an attempt to facilitate collaboration between the homeland and Canada. Political orientation may have represented a significant limitation to its operations. On the other hand, it has made an important contribution to economic and scientific cooperation between Slovenia and Canada.

Media are important supports for the social life of any ethnic community abroad. A crucial turning point in the life of Slovenians was the foundation in 1991 of a radio station called The Voice of Canadian Slovenians, which provided the community with cultural news, news about social events and reports from the homeland (Pospeh 2014). The Canadian Slovenian Historical Society is a unique experiment which aims to preserve the history of Slovenians in Canada. The society is also a member of the Archives Association of Ontario and the Canadian Oral History Association, and operates as a full member of the Ontario Historical Society. The main tasks are collection of materials and historical data, cataloguing materials, and publishing various publications regarding the life of Slovenians in Canada (CSHS 2017).

Small ethnic economies have often been financed by community banks or credit unions. The Slovenian community owns Moya Financial Credit Union Limited (amalgamation of previously separated Slovenia Parishes Credit Union Limited, with offices in Toronto and Hamilton, and the J. E. Krek Slovenian Credit Union based in Toronto). The concept of ethnic economy in some sense operates similarly to other community development projects in Canada, which are not necessary based on ethnicity but involve a similar pattern of social and economic institutions. Small credit unions play a crucial role in small economies, specifically assuring sustainability by offering micro-loans and similar services to members. As we will see below, the Canadian Slovenian Chamber of Commerce (CanSlo) has promoted further development through building business relations among ethnic business owners in Canada. Furthermore, there have been some serious experiments potentially strengthening collaboration between Slovenian and Canadian companies, for example the different understanding of the term "business culture", which 
led to a situation in which some Slovenian companies did not properly perceive business logic in Canada.

\section{Canadian economic history, immigration and the "footprint" of Slovenians}

The Laurier government's minister of the interior Clifford Sifton (1896-1905) foresaw how intensive migration could bring prosperity and further development especially in agriculture and industry. The plan was to settle the prairie areas of western Canada, especially the rural areas of present-day Alberta and Saskatchewan. In addition to British and white Americans, Sifton particularly encouraged Eastern and Central European farmers to immigrate to Canada (Strle 2009; Stasiulis 1997: 146). From Sifton's era there is only some fragmented data about the migration and economic activities of Slovenians in North America. One of the theses is that they largely came from the United States and worked as farmers, miners and ironworkers. The name M. Frankovič is mentioned, who presumably ran a hotel during this period. Several migrants travelled up north in search of gold (the gold rush era) (Strle 2009). Even the migrant workforce was planned mostly for agricultural products such as wheat, while many migrants started to work in mines, building railways or became part of the urban proletariat (Stasiulis 1997: 146).

Several private companies such as the Canadian Pacific Railway (acting as private corporate bodies) had become an extended hand of the state. Subagents of the same ethnicity produced "polarized class conditions" at railway companies (Stasiulis 1997: 147).In 1899, the North Atlantic Trading Company was established with significant backing from the Canadian government, where agents of the company tried as hard they could to attract agricultural labourers from Europe. The New Immigration Act (1906) clearly specified which ethnic groups would be more eligible to migrate to Canada. Specifically, certain groups were excluded from the list, such as criminals, the mentally disabled, and prostitutes, and some ethnic groups were privileged over the others, such as white American and British Protestants (Stasiulis 1997: 147). During the 1920s, Canadian agriculture was in crisis and many farmers moved to the US due to the poor economic conditions. By adopting a special Immigrant Law (1922), the Canadian government attracted new immigration from Europe while trying to satisfy the needs of the construction, transportation and mining sectors. At the end of decade, the government again limited migration from Central and Southern Europe, and several thousand Europeans were deported back to Europe due to radical changes in immigration policy. The period of the Great Depression clearly impacted the lives of Slovenians in Canada. Due to high rates of unemployment (around 27 percent or more) and the severe economic situation, many of them left Canada. Slovenian women played a major role in fulfilling the needs of the family budget during the crisis by working as maids, cooks, cleaners and washerwomen in boarding houses (Strle 2009).

The period from the end of the Second World War until the 1970s was a period of strong recovery of the Canadian economy. The US economy was the main consumer of Canadian products, and its own economic prosperity depended in a large measure on Canadian raw materials, especially due to the American role in the Cold War. The two main conclusions from the period are in fact the most relevant to this argument: (1) the US established greater control over Canadian manufacturing; (2) the US government and companies invested huge financial resources in the Canadian natural resource industry (Phillips, 
Watson 2001). An important goal of immigration policy at the beginning of the period was “... to allow enough immigrants to enter the country to meet domestic labour shortages but not enough to disrupt the Canadian labour market" (Knowles 2007: 163). The main goal of immigration was still increasing the prosperity of the national economy and increasing the population (Knowles 2007). The feminization of domestic work was also significant at that time (Stasiulis 2007: 151).

Important changes in Canadian immigrant policy occurred at the beginning of the 1970s. As a result of a broad consensus among the main political parties, 39,000 people from more than 150 countries were awarded the status of "Landed Immigrant". The Immigration Act of 1976 had a significant impact on future migration policy. The Act established a code which foresaw the obligatory consultation of the responsible minister with the provinces about immigration policy (Knowles 2007). As Strle (2009) pointed out, some sort of amalgamation of the "old" and "new" occupational statuses appeared in the 1970s. The most popular jobs for Slovenians were still in construction, mining, farming etc., but at the same time, Slovenians were also working as doctors, lawyers, engineers and university professors. In the last three decades or so, Canadian immigration policy has been intensively interwoven with fundamental global challenges. As Stasiulis (1997: 154) has stated, during the process of migration transnationalism, the investigation of the phenomena is becoming more and more complex due to numerous parameters that might affect the life of immigrants. The biggest Canadian cities, such as Toronto, Montreal and Vancouver, have become to some extent urban centres of international importance. Satzewitch and Wong (2003) placed transnational migrations in the context of the radical transformation of the modern Canadian economic structure.

\section{SLOVENIAN ETHNIC BUSINESS ACTIVITIES TODAY}

Having stated the above, it needs to be underlined that we could not find any relevant economic research concerning the ethnic business activities of Slovenians in Canada. The only source available is the business directory of the Canadian Slovenian Chamber of Commerce (i.e. CanSlo). Our initial assumptions are based on the analysis of 124 members of the Chamber, most of them of Canadian-Slovenian descent. A small number of companies and individuals from Slovenia are included as well. Due to this, we were able to define the structure of the Chamber as of a limited "transnational" character. The first impression is that the structure of Slovenian-Canadian ethnic business activities is highly diverse in terms of business categories even though, as shown in Table 1, some simplifications have been made using intermediate variables in order to merge some similarly-named categories. One of the most fundamental findings is that the structure of the sample is not very different to what it was in the past. There is a structural timeline difference due to the fact that many companies now use advanced technologies and entrepreneurs are far more educated, but the community does not operate solely as a business network. Some of the associations are of a non-profit nature or support community activities through business organisations such as credit unions. The latter is close to what have been defined as "social economy" tasks. The second interesting insight from the data is that there are some individual professionals employed within the mainstream economy (e.g. the banking sector) who are highly aware 
of their Slovenian origin and are prepared to help establish business relations within the community and between Slovenia and Canada (Notes on Fieldwork 2016).

Table 1: Structure of Slovenian Immigrant Business in Canada (including some Slovenian companies and individuals)

\begin{tabular}{|c|c|c|c|c|c|c|c|c|}
\hline \multirow[b]{2}{*}{ Main Business Categories ${ }^{\star *}$} & \multicolumn{2}{|c|}{ Country of Origin } & \multicolumn{6}{|c|}{ Type of Membership ${ }^{*}$} \\
\hline & Canada ${ }^{* * *}$ & Slovenia & MLB & SB & $\mathbf{P}$ & I (SP) & NP & S \\
\hline $\begin{array}{l}\text { Finance, industry constru- } \\
\text { ction, IT and web design, } \\
\text { machine shops, accounting, } \\
\text { banking, human resources, } \\
\text { consulting \& marketing, } \\
\text { real estate management, } \\
\text { non-profit organisations, } \\
\text { students, culture \& media, } \\
\text { credit unions. }\end{array}$ & 108 & 16 & $14 \mathrm{~L} / 26 \mathrm{M}$ & 54 & 9 & 6 & 6 & 6 \\
\hline
\end{tabular}

* Type of membership with actual fees paid for 2016

- Medium/Large Business (more than 10 employees): \$250

- Small Business (1-10 employees): \$ 100

- Professionals (employees of large firms): \$100

- Individuals / Sole proprietor (1-10 employees): \$ 100

- $\quad$ Non-Profit Organisations: 0

- Students: 0

** Business categories according to the "Search Directory" browser, intermediate variables established by the author due to the fact that some categories in the Directory are quite similar.

*** Almost all of the companies have their headquarters in the province of Ontario, largely in Toronto as the most prominent business metropolis. (Source: Adapted from the CanSlo Business Directory (2016))

It is clear that the definition of a "large business" is somewhat adapted to the needs of the membership structure. The minimum number of workers employed must be above 10 . This corresponds to Light and Gold's (2000) finding that the companies in ethnic economies are usually small, and mainly employ family members, close relatives and co-ethnics. So far, the actual internationalisation of ethnic business relations is still in the gestation phase. The first significant limitation is that Slovenia and Canada are totally different in terms of size, national economic structure and level of development. However, some very interesting facts are hidden behind this data. The Chamber includes mostly Ontario-based membership. Hypothetically, in the future, so-called province-state cooperation (Ontario-Slovenia) could be of greater relevance due to the fact that Slovenia is more easily comparable to the level of a province in Canada. Here is some basic data on economic cooperation between Slovenia and Canada showing the quite modest level of business cooperation: 
Table 2: Trade of goods between Slovenia and Canada, 2010-2017 (in EUR 1000) (Slovenian perspective)

\begin{tabular}{|c|c|c|c|c|}
\hline Year & Export & Import & Total & Balance \\
\hline 2011 & 57,778 & 25,797 & 83,575 & 31,981 \\
\hline 2012 & 71,217 & 103,875 & 175,092 & $-32,658$ \\
\hline 2013 & 60,422 & 106,102 & 166,524 & $-45,680$ \\
\hline 2014 & 58,820 & 68,521 & 127,341 & $-9,701$ \\
\hline 2015 & 70,115 & 32,022 & 102,137 & 38,093 \\
\hline 2016 & 71,772 & 103,954 & 175,726 & $-32,182$ \\
\hline $2017^{\star}$ & 23,342 & 10,012 & 33,354 & 13,330 \\
\hline
\end{tabular}

(Source: Export Window 2017 ( ${ }^{\star}$ data for 2017 not complete))

Regarding the possible internationalisation of ethnic business, some people believe that the current CETA agreement could be of great significance for future cooperation. It seems a quite intriguing theme, although the research that has been done (for example Damijan, Kostevc 2015) has not shown any major positive implications for the Slovenian economy, except some deregulatory disburdening. According to Pospeh (2009), we can conclude that around 250 entrepreneurs of Slovenian origin operated in the Toronto area at that time. As we have already shown above, these are more or less small family firms owned nowadays by the second generation of the original immigrants.

Another of our intentions is to show the business potential of the Slovenian community in Canada in terms of the better integration of the newcomers from Slovenia. The latter is especially important with regard to the latest wave of migration from Slovenia to Canada following the global financial crisis after 2007. Informal conversations with some Slovenians who migrated in the last decade have shown that they used the ethnic network in order to integrate more quickly into Canadian society (Notes on Fieldwork 2016).

On the other hand, Fong and Oka (2002) have offered a contrasting picture, showing in the case of Chinese immigrants in Toronto that an ethnic economy can also hold back processes of integration. A potentially relevant assumption in this sense might be that Slovenian and Chinese ethnic structures are very different, especially in terms of the size of the businesses and number of co-ethnics. Chinese immigrants have established a much larger and self-reliant ethnic economic subsystem that operates far more independently than some micro-structures such as in the Slovenian case. Fong and Oka explain that such a big subsystem may have its own language practises and intensive internal connections. In conditions of transnational entrepreneurship, previously ethnic-based organisations have become serious players in international trade. Within the Chinese community, the Toronto Chinese Business Association (TCBA) acts as an important intermediary in Canadian-Chinese business relations and serves as a platform for Chinese ethnic business activities in metropolitan Toronto (TCBA 2017). Similarly, the Chinese Business Chamber of Canada (CBCC) represents over 1300 different business establishments. It has its own Immigrant Assistance Centre offering free assistance to Chinese immigrants and those who want to set up a business in Canada (CBCC 2017). Relevant data dating back to 2006 shows that Chinese entrepreneurs accounted for $12 \%$ of the ethnic workforce and created 600,000 jobs for both Chinese and non-Chinese workers. Chinese ethnic business 
activities are represented in certain specific industries: retail trade, technical services, health care and social assistance, accommodation and food services etc. (Li 2010).

According to the documents and reports of the CanSlo Chamber, activities have been oriented mostly towards organising various business events in order to promote ethnically-based and other entrepreneurship and opportunities to do business with Slovenia. A Toronto city councillor (also a Canadian Slovenian), for example, presented the city's strategic development plans for small and medium-sized companies in the near future. One of the business events (held as a workshop) was organised in order to present Slovenian wines and business opportunities for Canadian companies in the field of tourism and trade with Slovenia. Furthermore, due to the interest demonstrated among the members, a workshop on the new retirement law of the province of Ontario was held. Cooperation with large companies (such as the Bank of Montreal) has been established. The Chamber has also made extensive contacts with some Canadian politicians. It has also promoted itself at various political events, specifically in terms of networking (CanSlo Annual Report 2015). The Chamber also operates actively in Slovenia. It was presented at the MOS International Trade and Business Fair in Celje, the largest business fair in the region of Central/South-Eastern Europe. The Canadian business environment was promoted at the Slovenian Chamber of Commerce and Industry and at several other places including University of Ljubljana. An important collaboration was also established with the SPIRIT Slovenia Public Agency for Entrepreneurship, Internationalization, Foreign Investments and Technology.

\section{CONCLUSION}

We need to note that the research is limited by a lack of relevant quantitative data concerning an economic approach to Slovenian immigration. We cannot overlook the fact that the Slovenian community is small and as such is not a very intriguing subject for research in the field of political economy, where scholars prefer to explore bigger and more influential ethnic groups for the Canadian economy. One of the key conclusions is that Slovenians have never been completely assimilated into mainstream Canadian society. In fact, they have developed their own support institutions and also operated as an integral part of a dominant social economic system in Canada. The structure of the Slovenian ethnic and social economy can be understood as having strongly motivated its members to be actively involved in the prevalent capitalist mode of production.

Several other ethnic groups of much bigger size and influence have established completely isolated economic and social ethnic substructures. In this sense, the example of Chinese immigrants in Toronto described by Fong and Oka (2002) clearly illustrates the real differences between large and small ethnic economies. There is clear internationalisation of Slovenian ethnic business activities. As mentioned above, we can speak only of an extremely limited extent of transnationalism; only an embryonic network has been established. According to Žigon (2012), the lack of intensive development of similar structures is mainly a result of the fact that the so-called ethnic business relations are maintained not so much in the name of a profit but more as a result of the symbolic affiliation with the ethnic group and identity-building. 
Immigration is a continuous process. Looking at the latest movement of Slovenians to Canada, it is evident that the ethnic structure is still relevant as a "support unit" for the newcomers. As the author has observed, several new Slovenian immigrants in the Toronto area have not only become members of the business community, but also quickly established successful small- and medium-sized companies. Last but not least, we should mention the widely-known case of a Slovenian entrepreneur who recently migrated to Canada and transferred his business and the related technology and know-how from Slovenia directly to the Canadian market (Notes on Fieldwork 2016).

\section{REFERENCES}

A New Plan for Canadian Immigration and Economic Opportunity, https://www.liberal. $\mathrm{ca} /$ realchange/a-new-plan-for-canadian-immigration-and-economic-opportunity/?shownew=1 (3. 5. 2017).

Canadian Slovenian Chamber of Commerce (2016). Annual Report 2016 (internal documentation). Toronto.

Canadian Slovenian Historical Society (CSHS), http://www.slovenianhistorical.ca/ (4. 6. 2017).

Chinese Business Chamber of Canada (CBCC), http://chinesebusiness.org/chamber_ en.phtml (4. 6. 2017).

Damijan, Jože P., Kostevc, Črt (2015). Vpliv Comprehensive Economic and Trade Agreement na slovensko gospodarstvo. Ljubljana: Center poslovne odličnosti Ekonomske fakultete.

Dungan, Peter, Fang, Tony, Gunderson, Morley (2012). Macroeconomic Impacts of Canadian Immigration: Results from a Macro-Model. IZA DP No. 6743. Toronto: Institute for the Study of Labor.

Durnik, Mitja (2009). Canadian Public Policy and Poverty of Aboriginals. Doctoral Dissertation. Ljubljana: Faculty of Social Sciences.

Durnik, Mitja (2016) Notes on Fieldwork in Toronto. Author's personal archive.

Fong, Eric, Ooka, Emi (2002). The Social Consequences of Participating in the Ethnic Economy. International Migration Review 36/1, 25-146.

Fong, Eric, Xingshan, Cao, Chan, Elic (2010). Out of Sight, Out of Mind? Patterns of Transnational Contact Among Chinese and Indian Immigrants in Toronto. Sociological Forum 25/3, 428-449.

Frisbie, Parker (1975). Illegal Migration from Mexico to the United States: A Longitudinal Analysis. International Migration Review 9, 3-13.

Genorio, Rado (1979). Prispevek h geografiji slovenskega izseljenstva. Geografski vestnik LI, 44-53.

Genorio, Rado (1989). Slovenci v Kanadi / Slovenes in Canada. Ljubljana: Inštitut za geografijo Univerze Edvarda Kardelja (Geographica Slovenica, 17).

Gignac, Clement (2016). For Canada, Immigration is a Key to Prosperity. The Globe and Mail, https://www.theglobeandmail.com/report-on-business/economy/economy-lab/ for-canada immigration-is-a-key-to-prosperity/article14711281/ (3. 6. 2017).

Izvozno okno (Export Window) (2016). Bilateralni ekonomski odnosi Kanade s Slovenijo, http://www.izvoznookno.si/Dokumenti/Podatki_o_drzavah/Kanada/Bilateralni_ ekonomski_odnosi_s_Slovenijo_4134.aspx (4.6.2017).

Judt, Tony (2007). Postwar: A History of Europe Since 1945. London: Random House. 
Knowles, Valerie (2007). Canadian Immigration and Immigration Policy, 1540-2006. Toronto: Dundurn Press.

Li, Peter S. (2010). Chinese Entrepreneurship in Canada. Open for Business Migrant Entrepreneurship in OECD Countries. OECD Publishing, 199-212.

Light, Ivan, Gold, Steven J. (2000). Ethnic Economies. London: Academic Press

Lowe, Keith (2012). Savage Continent: Europe in the Aftermath of World War II. London: Penguin.

Mesić, Milan (2002). Međunarodne migracije: Tokovi i teorije. Zagreb: Societas.

Milanović, Branko (2016). Global Inequality: A New Approach for the Age of Globalization. Cambridge, MA: Harvard University Press.

Phillips, Paul, Watson, Stephen (2001). From Mobilization to Contientalism: The Canadian Economy in the Post-Depression Period. Essays in the Historical Political Economy of Canada (ed. Paul Phillips). Unpublished Study Material. Winnipeg: University of Manitoba.

Picketty, Thomas (2014). Capital in the Twenty-First Century. Cambridge, MA: Harvard University Press

Porumbescu, Alexandra (2015). Defining the New Economics of Labor Migration Theory Boundaries: A Sociological-Level Analysis of International Migration. RSP 45, 55-64.

Pospeh, Stanislav (2009). Slovenska migracija v Kanadi. Magistrsko delo. Ljubljana: Fakulteta za družbene vede.

Riddell, Craig, Worswick, Christopher, Green David A. (2016). Evidence Shows that Increased Immigration has Neither Positive nor Negative Impacts on Jobs and Wages, but More Research is Needed, http://policyoptions.irpp.org/magazines/november-2016/ how-does-increasing-immigration-affect-economy/ (1. 6. 2017).

Satzewich, Vic, Wong, Lloyd (2003). Immigration, Ethnicity and Race: The Transformation of Transnationalism, Localism and Identities. Changing Canada: Political Economy as Transformation (eds. Wallace Clement, Leah Vosko). Montreal, Kingston: McGillQueen's University Press, 363-390.

Simmons, Alan (2010). Immigration and Canada: Global and Transnational Perspectives. Toronto: Canadian Scholars' Press Inc.

Stasiulis, Daiva (1997). The Political Economy of Race, Ethnicity and Migration. Understanding Canada: Building on the New Political Economy (ed. Clement Wallace). Montreal: MgGill-Quenn's University Press, 141-171.

Strle, Urška (2007). Odnos slovenskih izseljencev v Kanadi do matične domovine po drugi svetovni vojni. Dve domovini / Two Homelands 26, 117-142.

Strle, Urška (2009). Slovenci v Kanadi: Izseljevanje skozi prizmo življenjskih zgodb. Doktorska disertacija. Ljubljana: Filozofska fakulteta.

Strle, Urška (2012). Podobe kanadskih Slovencev / Images of Canadian Slovenians. Razstava, Atrij ZRC, Ljubljana (SLO), 20. jun.-20. jul. Virtualna prezentacija Mitja Durnik.

The Canadian Slovenian Chamber of Commerce Business Directory (2016). Internal Documentation of the Canadian Slovenian Chamber of Commerce. Toronto.

Toronto Chinese Business Association (TCBA), http://www.tcbacanada.com/ (2. 4. 2017).

Vah Jevšnik, Mojca, Lukšič Hacin, Marina (2011). Theorising Immigrant/Ethnic Entrepreneurship the Context of Welfare States. Migracijske i etničke teme 27/2, 249-261.

Žigon, Zvone (2012). Etnična ekonomija in Slovenci zunaj Republike Slovenije (unpublished). 


\section{POVZETEK}

\section{SLOVENSKI PRISELJENCI IN ETNIČNA EKONOMIJA SODOBNE KANADE Mitja DURNIK}

Avtor se v članku ukvarja z etnično ekonomijo slovenske skupnosti v Kanadi, ki je bila v strokovni in znanstveni literaturi do sedaj le deskriptivno obravnavana; primanjkujejo namreč za poglobljeno analizo nujni viri podatkov. Kljub temu je iz analize mogoče razbrati nekatere vzorce etničnega podjetništva Slovencev, ki se je vedno naslanjalo na lastne družbene in skupnostne institucije. Slovenska skupnost se v nobeni točki lastnega družbenega in ekonomskega razvoja ni popolnoma asimilirala v dominantni sistem gospodarjenja, temveč je skušala s sodelovanjem posameznikov in institucij ohranjati lastno identiteto. Avtor pritrjuje nekaterim opažanjem drugih avtorjev, da sta podjetniški interes in gospodarsko sodelovanje $\mathrm{v}$ preteklosti v veliki meri prevladala nad političnimi spori v skupnosti. Zlasti zadnji val priseljevanja Slovencev med svetovno finančno in gospodarsko krizo se zdi izrazito ekonomske narave. Interes gospodarsko povezati slovenske in kanadske gospodarstvenike se vedno bolj kaže tudi v kanadski etnični ekonomiji in njenih institucijah. Primerjava z največjo, kitajsko etnično skupnostjo pa jasno pokaže, da se zmogljivost etnično zasnovanih poslovnih klubov ali zbornic, ko gre za dve veliki državi, popolnoma razlikuje od slovenskih. Ne smemo prezreti dejstva, da se poslovna funkcija v slovenski etnični skupnosti kljub vsemu razvija hkrati z razvojem globalnega sveta, katerega majhen del je tudi sama. 